\title{
Potential Association Between Perioperative Fluid Management and Occurrence of Postoperative lleus
}

\author{
Fabian Grass, M.D. ${ }^{1,2} \bullet$ Jenna K. Lovely, Pharm.D., R.Ph., B.C.P.S. ${ }^{3}$ \\ Jacopo Crippa, M.D. ${ }^{1}$ - Martin Hübner, M.D. ${ }^{2}$ Kellie L. Mathis, M.D., M.Sc ${ }^{1}$ \\ David W. Larson, M.D., M.B.A. ${ }^{1}$ \\ 1 Division of Colon and Rectal Surgery, Mayo Clinic, Rochester, Minnesota \\ 2 Department of Visceral Surgery, Lausanne University Hospital, Lausanne, Switzerland \\ 3 Hospital Pharmacy Services, Mayo Clinic, Rochester, Minnesota
}

BACKGROUND: Postoperative ileus remains an issue after colorectal surgery delaying recovery and increasing the length of hospital stay and costs.

OBJECTIVE: The purpose of this study was to analyze the impact of perioperative fluid management on ileus occurrence after colorectal surgery within a fully implemented enhanced recovery pathway.

DESIGN: This was a retrospective cohort study of a prospectively maintained institutional database.

SETTINGS: The study was conducted at a tertiary academic facility with fully implemented standardized enhanced recovery pathway over the entire study period.

PATIENTS: All of the consecutive elective major colorectal resections for benign or malign indications between 2011 and 2016 were included.

MAIN OUTCOME MEASURES: Postoperative ileus was defined as the need for nasogastric tube reinsertion. Perioperative fluid management and surgical outcome were compared between patients presenting with ileus and those without. Potential risk factors for ileus were identified through multinomial logistic regression.

RESULTS: Postoperative ileus occurred in 377 (9\%) of 4205 included patients at day 4 (interquartile range, $2-5$

Funding/Support: None reported.

Financial Disclosures: None reported.

Correspondence: David W. Larson, M.D., M.B.A., Division of Colon and Rectal Surgery, Mayo Clinic, 200 First Street SW, Rochester, MN 55905. E-mail: larson.david2@mayo.edu

Dis Colon Rectum 2020; 63: 68-74

DOI: 10.1097/DCR.0000000000001522

(c) The ASCRS 2019 d). Intraoperatively, ileus patients received $3.2 \pm 2.6 \mathrm{~L}$ of fluids, whereas the remaining patients received $2.5 \pm 1.7 \mathrm{~L}$ $(p<0.001)$. Weight gain was $3.8 \pm 7.1 \mathrm{~kg}$ in ileus patients versus $3.0 \pm 6.6 \mathrm{~kg}(p=0.272)$ in the remaining patients at postoperative day $1,4.4 \pm 6.5 \mathrm{~kg}$ versus $3.1 \pm 7.0 \mathrm{~kg}$ $(p=0.028)$ at postoperative day 2 , and $1.8 \pm 6.0 \mathrm{~kg}$ versus $0.0 \pm 6.0 \mathrm{~kg}$ at discharge $(p=0.002)$. The multivariable model including all significant $(p<0.05)$ demographic, fluid management-related, and surgical parameters retained postoperative day 0 fluids of $>3 \mathrm{~L}(\mathrm{OR}=1.65$ (95\% CI, 1.13-2.41); $p=0.009)$, postoperative day 2 weight gain of $>2.5 \mathrm{~kg}(\mathrm{OR}=1.49$ (95\% CI, 1.01-2.21); $p$ $=0.048)$, and occurrence of postoperative complications $(\mathrm{OR}=2.00$ (95\% CI, 1.39-2.90); $p<0.001)$ as independent risk factors for ileus.

LIMITATIONS: This study was limited by its retrospective design. Fluid management depends on patient-, disease-, and surgery-related factors and cannot be generalized and extrapolated.

CONCLUSIONS: Fluid overload and occurrence of postoperative complications were independent risk factors for postoperative ileus. This calls for action to keep perioperative fluids below suggested thresholds. See Video Abstract at http://links.lww.com/DCR/B54.

\section{ASOCIACIÓN POTENCIAL ENTRE EL MANEJO DEL LÍQUIDO PERIOPERATORIO Y EL SUCESO DE ÍLEO POSTOPERATORIO}

ANTECEDENTES: El íleo postoperatorio sigue siendo un problema después de una cirugía colorrectal que retrasa la recuperación y aumenta la duración de la estancia hospitalaria y los costos.

OBJETIVO: Analizar el impacto del manejo del líquido perioperatorio en la incidencia de íleo después de la 
cirugía colorrectal dentro de una vía de recuperación mejorada totalmente implementada.

DISEÑO: Estudio de cohorte retrospectivo de una base de datos institucional mantenida prospectivamente.

MARCO: Centro académico terciario con una ruta de recuperación mejorada estandarizada completamente implementada durante todo el período del estudio.

PACIENTES: Se incluyeron todas las resecciones colorrectales mayores electivas consecutivas para indicaciones benignas o malignas entre 2011 y 2016.

MEDIDAS DE RESULTADOS PRINCIPALES: El íleo postoperatorio se definió como la necesidad de reinserción de la sonda nasogástrica. El manejo del líquido perioperatorio y el resultado quirúrgico se compararon entre los pacientes con íleo y los que no. Los posibles factores de riesgo para el íleo se identificaron mediante regresión logística multinominal.

RESULTADOS: El íleo postoperatorio se ocurrió en 377 (9\%) de los 4205 pacientes incluidos al cuarto día (RIC 2-5). Intraoperatoriamente, los pacientes con íleo recibieron $3.2 \pm 2.6 \mathrm{~L}$ de líquidos, mientras que los pacientes restantes recibieron $2.5 \pm 1.7 \mathrm{~L}(p<0.001)$. El aumento de peso fue de $3.8 \pm 7.1 \mathrm{~kg}$ en pacientes con íleo versus $3 \pm 6.6 \mathrm{~kg}(p=0.272)$ en los pacientes restantes en el día postoperatorio $1,4.4 \pm 6.5 \mathrm{~kg}$ vs. $3.1 \pm 7 \mathrm{~kg}(p=0.028)$ en el día postoperatorio $2 \mathrm{y}$ $1.8 \pm 6 \mathrm{~kg}$ versus a $0 \pm 6 \mathrm{~kg}$ al tiempo de alta hospitalaria $(p=0.002)$. El modelo multivariable que incluye todos los parámetros demográficos, del manejo de líquidos y quirúrgicos significativos $(p<0.05)$ mantuvo líquidos del día 0 después de la operación de $>3 \mathrm{~L}$ (proporción de probabilidad 1.65, intervalo de confianza del 95\% $1.13-2.41, p=0.009$ ), ganancia de peso de $>2.5 \mathrm{~kg}$ en el dia postoperatorio 2 (proporción de probabilidad $1.49,95 \%$ intervalo de confianza 1.01-2.21, $p=0.048)$ y aparición de complicaciones postoperatorias (proporción de probabilidad 2, 95\% intervalo de confianza 1.39-2.9, $p$ $<0.001)$ como factores de riesgo independientes para íleo.

LIMITACIONES: Diseño retrospectivo. El manejo de líquidos depende de factores relacionados con el paciente, la enfermedad y la cirugía, y no puede generalizarse ni extrapolarse.

CONCLUSIONES: La sobrecarga de líquidos y la aparición de complicaciones postoperatorias fueron factores de riesgo independientes para el íleo postoperatorio. Esto requiere medidas para mantener los líquidos perioperatorios por debajo de los umbrales sugeridos. Vea el Video del Resumen en http://links.lww.com/DCR/B54.

KEY WORDS: Colorectal; Enhanced recovery; Fluids; Ileus.
$\mathrm{P}$ ostoperative ileus (POI) remains a major problem after colorectal surgery, delaying recovery and increasing length of hospital stay and costs. ${ }^{1,2}$ Numerous POI-preventing measures have been tested through randomized controlled trials, including systematic administration of gastrografin, ${ }^{3,4}$ alvimopan, ${ }^{5}$ chewing gum, ${ }^{6,7}$ or epidural analgesia, ${ }^{8,9}$ with inconsistent or ambiguous results. Restrictive perioperative fluid management may be another way to prevent POI according to several historical and recent reports. ${ }^{10,11}$ However, caution is warranted, because overly restrictive therapy may result in acute kidney injury (AKI) in traditional care settings. ${ }^{12}$ The present study aimed to assess the impact of perioperative fluid management on the occurrence of POI after colorectal resections within a comprehensive enhanced recovery pathway (ERP).

\section{PATIENTS AND METHODS}

\section{Patients}

This is a retrospective cohort study of prospectively recorded data from the institutional electronic ERP database at the Mayo Clinic. All of the consecutive elective major colorectal resections (including left, right, (sub-) total, and segmental colectomies and rectal resections) for benign or malign indications between 2011 and 2016 were included. Excluded were local rectal excisions, stoma procedures (ostomy closures and Hartmann reversals), and hernia repairs. This study was approved by the institutional review board as part of an enhanced recovery quality improvement project.

The institutional ERP was initiated by November 2009, implemented over 2010, and accepted as a division standard of practice as of January 2011 in the Department of Colon and Rectal Surgery. Contents of the database have been repeatedly described in previous institutional publications demonstrating high compliance and improved short-term outcomes by the use of ERP. ${ }^{13-16}$ Briefly, the pathway focuses on a multimodal opioid-sparing pain management strategy including intrathecal and excluding epidural analgesia, ${ }^{16,17}$ postoperative nausea and vomiting (PONV) prophylaxis (systematic gabapentin administration), restrictive intraoperative fluid management, and early resumption of normal diet and ambulation, in line with the recommendations of the American Society of Enhanced Recovery. ${ }^{18,19}$ Nasogastric tubes (NGTs) were routinely removed before the reversal of anesthesia.

\section{Fluid Management}

A restrictive intraoperative fluid administration policy was applied in the setting of the institutional ERP to aim for euvolemia and zero fluid balance. ${ }^{18}$ The perioperative concept additionally included allowance of clear fluids until 2 hours before the induction of anesthesia. Postoperatively, patients had unrestricted access to oral fluids (providing tolerated). 
The principles that were adhered to were in line with the recommendations of the American Society for Enhanced Recovery. ${ }^{18}$ In normovolaemic patients, blood pressure was maintained using vasopressors to avoid fluid overload. In isolation, intraoperative oliguria was not considered harmful and did not guide fluid resuscitation. A goal-directed fluid management strategy with invasive monitoring was reserved for high-risk cases or procedures according to anesthesiologist assessment, preferentially through invasive blood pressure monitoring and/or stroke volume assessment with esophageal Doppler technology. ${ }^{20}$ Intravenous (IV) fluids (preferentially isotonic chloride-restrictive crystalloids, colloids, packed red blood cells, and albumin) administered intraoperatively, at the postanesthesia care unit and at the surgical ward until saline lock at 8:00 $\mathrm{Am}$ at postoperative day (POD) 1 were totaled to calculate total IV fluids at POD 0. Additional data gathered included the amounts of IV and ingested oral fluids through POD 2.

Weight was assessed preoperatively (within 1 mo of surgery) and on POD 1, 2, and at discharge. For the purpose of this study, the following cutoffs were chosen for fluid administration: POD 0 IV fluids of $3 \mathrm{~L}$ and POD 2 weight gain of $2.5 \mathrm{~kg}$. These cutoffs derive from an independent cohort, indicate critical fluid management-related thresholds, and were used for the first time in this present study for external validation. ${ }^{21}$

\section{Outcomes}

POI was defined as need for NGT reinsertion in-hospital or until 30 days postoperatively. ${ }^{22}$ Timing of NGT reinsertion was recorded. Risk factors for POI were identified among patient-, surgery- and fluid management-related items. In a second step, multivariable analysis was performed to assess the impact of univariate significant risk factors and above-defined fluid management-related cutoffs on POI occurrence. Overall and specific surgical complications (bleeding (need for transfusion), surgical site infection (SSI) needing invasive treatment (surgical, percutaneous, or negative wound pressure therapy), anastomotic leak (clinically or radiologically confirmed), AKI (defined as postoperative creatinine increase $\times 1.5$ ), reoperation rate, and reasons for reoperation in patients with POI) and readmission rate were assessed in hospital and until 30 days postoperatively and compared between both groups (POI versus no POI). Only index surgeries were retained for this analysis, whereas no patient was excluded according to an intention-to-treat principle. When reoperation occurred, POI was not assessed beyond the surgical intervention because of the nonelective character of reoperations.

\section{Statistical Analysis}

Descriptive statistics for categorical variables were reported as frequency (percentage) and continuous variables as mean (SD) or median (interquartile range (IQR)), as appropriate. The $\chi^{2}$ test was used to compare categorical variables. All of the statistical tests were 2 sided, and a level of 0.05 was used to indicate statistical significance. Significant variables were entered into a multivariable logistic regression (based on a probit regression model) to provide adjusted estimations of the OR. Data analysis was performed with the SPSS Advanced Statistics 22 (IBM Software Group, Chicago, IL).

\section{RESULTS}

POI occurred in 377 (9\%) of 4205 patients at day 4 (IQR, $2-5 \mathrm{~d})$. Demographic and surgical details are displayed in Tables 1 and 2. Ileus rates according to type of surgery were $6.3 \%$ after left colectomy, $8.6 \%$ after right colectomy, $10.0 \%$ after rectal surgery, $11.2 \%$ after segmental/transverse colectomy, and $11.4 \%$ after total colectomy $(p=0.05)$.

IV fluids and oral fluid intake differed significantly through POD 0 to 2 between patients with POI and those without. Intraoperatively, ileus patients received $3.16 \pm 2.55 \mathrm{~L}$ of fluids, whereas the remaining patients received $2.48 \pm 1.65 \mathrm{~L}(p<0.001)$. When assessing total POD 0 fluids year to year, no significant patterns toward increased or decreased compliance over time could be observed (2011: $3.2 \pm 1.6 \mathrm{~L}, 2012: 3.2 \pm 1.6 \mathrm{~L}, 2013: 3.2 \pm 1.9 \mathrm{~L}, 2014$ : 3.1 $\pm 2.2 \mathrm{~L}, 2015: 3.3 \pm 1.9 \mathrm{~L}, 2016: 3.2 \pm 1.8 \mathrm{~L})$. On POD 0, 236 ileus patients $(63 \%)$ received $>3 \mathrm{~L}$ compared with 1683 patients $(44 \%)$ of the group without ileus $(p<0.001)$. Likewise, postoperative weight gain differed at POD 2 and at discharge: whereas patients without ileus regained their initial weight before discharge, ileus patients were dismissed with a weight excess of $1.8 \pm 6.0 \mathrm{~kg}(p=0.002)$. Weight gain of $>2.5 \mathrm{~kg}$ at POD 2 was observed more often in ileus patients $(68 \%$ vs $56 \% ; p=0.008)$. Postoperative IV and oral fluids are displayed in Figure 1. Oral fluid ingestion averaged $6.0 \pm 5.5$ versus $6.0 \pm 4.8 \mathrm{~mL} / \mathrm{kg}$ on POD $0(p=0.944)$, $16.8 \pm 9.1$ versus $18.2 \pm 8.6 \mathrm{~mL} / \mathrm{kg}$ on POD $1(p=0.021)$, and $13.1 \pm 8.9$ versus $15.7 \pm 8.8 \mathrm{~mL} / \mathrm{kg}$ on POD $2(p<0.001)$.

Table 3 displays overall and specific postoperative complications other than POI in both groups. Anastomotic leaks, SSI, and reoperations occurred at a median POD 5 (IQR, 3-8), 9 (IQR, 4-15), and 3 (IQR, 1-10). Median length of stay differed significantly among the 2 groups $(9$ $\mathrm{d}$ in ileus patients vs $4 \mathrm{~d}$ in remaining patients; $p<0.001$ ). Reasons for reoperation in patients with POI included the following: wound issues including superficial SSI and wound/abdominal wall dehiscence (35\%), intra-abdominal sepsis including leaks (28\%), small bowel obstruction (17\%), bleeding complications (14\%), and other (6\%).

The multivariable model including all of the significant $(p<0.05)$ demographic, fluid management-related, and surgical parameters retained POD 0 fluids of $>3 \mathrm{~L}(\mathrm{OR}=$ 1.65 (95\% CI, 1.13-2.41); $p=0.009$ ), POD 2 weight gain 
TABLE 1. Demographics

\begin{tabular}{|c|c|c|c|c|}
\hline Item & $\begin{array}{c}\text { All } \\
(n=4205)\end{array}$ & $\begin{array}{c}\text { lleus } \\
(n=377)\end{array}$ & $\begin{array}{l}\text { No ileus } \\
(n=3828)\end{array}$ & $p$ \\
\hline Age, mean $\pm S D, y$ & $55.6 \pm 18.0$ & $57.4 \pm 17.7$ & $55.4 \pm 18.1$ & $0.04^{*}$ \\
\hline Age $\geq 70$ y, n (\%) & $1017(24.2)$ & $97(25.7)$ & $920(24.0)$ & 0.49 \\
\hline Sex, men, $\mathrm{n}(\%)$ & $2147(51.1)$ & $229(60.7)$ & $1918(50.1)$ & $0.00008^{*}$ \\
\hline $\mathrm{BMI}$, mean $\pm \mathrm{SD}, \mathrm{kg} / \mathrm{m}^{2}$ & $27.4 \pm 6.5$ & $27.7 \pm 9.6$ & $27.4 \pm 6.1$ & 0.53 \\
\hline $\mathrm{BMI} \geq 30 \mathrm{~kg} / \mathrm{m}^{2}, \mathrm{n}(\%)$ & $1171(27.8)$ & $108(28.6)$ & $1063(27.1)$ & 0.72 \\
\hline ASA group ( $\geq 3), n(\%)$ & $1183(28.7)$ & $143(38.3)$ & $1040(27.2)$ & $0.00009^{*}$ \\
\hline Diabetes mellitus, n (\%) & $437(10.4)$ & $51(13.5)$ & $386(10.1)$ & $0.04^{*}$ \\
\hline Preop albumin, mean $\pm S D, g / d L$ & $3.99 \pm 0.59$ & $3.85 \pm 0.62$ & $4.00 \pm 0.58$ & $0.005^{*}$ \\
\hline$<3.5 \mathrm{~g} / \mathrm{dL}, \mathrm{n} / \mathrm{N}(\%)$ & $338 / 1686(20)$ & $47 / 158(30)$ & $\begin{array}{c}291 / 1528 \\
(19)\end{array}$ & $0.002^{*}$ \\
\hline Preop hemoglobin, mean $\pm \mathrm{SD}, \mathrm{g} / \mathrm{dL}$ & $12.2 \pm 2.2$ & $11.6 \pm 2.2$ & $12.3 \pm 2.2$ & $0.003^{*}$ \\
\hline$<12.0 \mathrm{~g} / \mathrm{dL}, \mathrm{n} / \mathrm{N}(\%)$ & $357 / 830(43)$ & $57 / 104(55)$ & $300 / 726(41)$ & $0.01 *$ \\
\hline Preop creatinine, mean $\pm \mathrm{SD}, \mathrm{mg} / \mathrm{dL}$ & $0.94 \pm 0.38$ & $0.96 \pm 0.41$ & $0.94 \pm 0.37$ & 0.42 \\
\hline Preop WBC count, mean \pm SD, ${ }^{*} 10^{3} / \mu \mathrm{L}$ & $7.6 \pm 4.3$ & $8.4 \pm 5.5$ & $7.5 \pm 4.2$ & $0.006^{*}$ \\
\hline$>11^{*} 10^{3} / \mu \mathrm{L}, \mathrm{n} / \mathrm{N}(\%)$ & $451 / 3831(12)$ & $59 / 359(16)$ & $\begin{array}{c}392 / 3472 \\
(11)\end{array}$ & $0.006^{*}$ \\
\hline
\end{tabular}

Data show the baseline demographic parameters of patients with postoperative ileus $(n=377)$ and patients without postoperative ileus $(n=3828)$.

WBC $=$ white blood cell count; Preop $=$ preoperative.

${ }^{*} P$ value $<0.05$ is significant.

TABLE 2. Surgical details

\begin{tabular}{|c|c|c|c|c|}
\hline Item & $\begin{array}{c}\text { All } \\
(n=4205)\end{array}$ & $\begin{array}{c}\text { Ileus } \\
(n=377)\end{array}$ & $\begin{array}{l}\text { No ileus } \\
(n=3828)\end{array}$ & $p$ \\
\hline Malignancy, n (\%) & $2733(65)$ & $249(66)$ & $2484(65)$ & 0.65 \\
\hline Minimally invasive approach, $\mathrm{n}(\%)$ & $1939(46)$ & $139(37)$ & $1800(47)$ & $0.0002^{*}$ \\
\hline Left colectomy, n (\%) & $1019(24.2)$ & $64(17.0)$ & 955 (24.9) & $0.0006^{*}$ \\
\hline Right colectomy, n (\%) & $1048(24.9)$ & $90(23.6)$ & $958(25.0)$ & 0.66 \\
\hline Segmental/transverse colectomy & $98(2.3)$ & $11(2.9)$ & $87(2.3)$ & 0.38 \\
\hline Operation duration, mean $\pm S D$, min & $200 \pm 98$ & $228 \pm 121$ & $198 \pm 95$ & $0.00003^{*}$ \\
\hline Operation duration >180 min, $\%$ & $2087(49.6)$ & $229(60.7)$ & $1858(48.5)$ & $<0.0001^{*}$ \\
\hline
\end{tabular}

Data show the surgical parameters of patients with postoperative ileus $(n=377)$ and patients without postoperative ileus $(n=3828)$.

*P value $<0.05$ is significant.

of $>2.5 \mathrm{~kg}(\mathrm{OR}=1.49(95 \% \mathrm{CI}, 1.01-2.21) ; p=0.048)$, and occurrence of postoperative complications $(\mathrm{OR}=2.00$ (95\% CI, 1.39-2.90) as independent risk factors for POI (Fig. 2).

\section{DISCUSSION}

This large series of consecutive, unselected patients undergoing colorectal resections within a comprehensive ERP over a 6-year study period revealed an ileus rate of $9 \%$. Fluid management seemed to play a pivotal role because, despite the strong impact of postoperative complications, both surrogates of fluid overload, POD 0 IV fluids of $>3 \mathrm{~L}$ and POD 2 weight gain of $>2.5 \mathrm{~kg}$ were retained as independent risk factors for POI on multivariable analysis. This study hence provides external validation of these recently proposed thresholds, which could be useful as guidance in clinical practice.
A recent meta-analysis of 26 prospective and 28 retrospective studies revealed a POI incidence of $10.3 \%,{ }^{23}$ similar to the observed rate in the present cohort. However, even higher rates of up to $20 \%$ are consistently reported from large cohort studies, ${ }^{24-26}$ and treatment and prevention of POI are only partially effective. ${ }^{27}$ The multimodal enhanced recovery concept has been described as an efficient way to decrease POI through decreased perioperative surgical stress. ${ }^{28,29}$

Despite an abundance of reports dealing with pathophysiological mechanisms responsible for POI, the exact pathogenesis remains matter of ongoing debate. ${ }^{27} \mathrm{~A}$ complex interaction of inflammation and neurohumoral mechanisms disrupts GI motility after surgery. ${ }^{30}$ Other than a physiological response to manual intestinal manipulation triggered by complex neurohumoral responses (physiologic ileus), additional factors such as infection, perioperative opioid use, surgical stress response, delayed nutrition, and potential intraoperative and postoperative complications 
A IV fluids

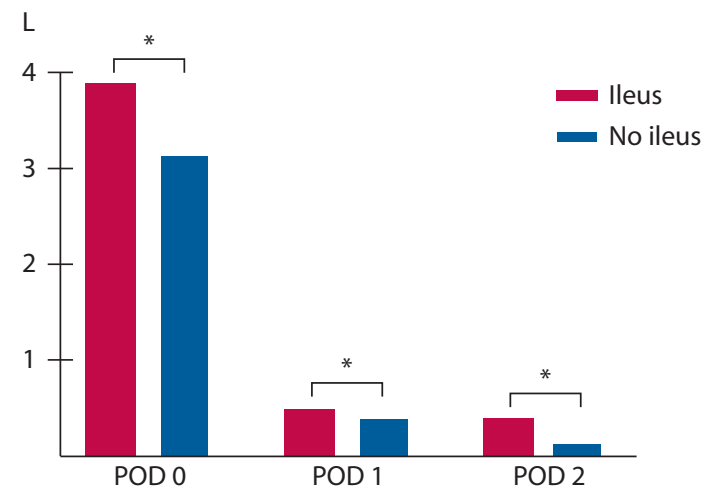

B

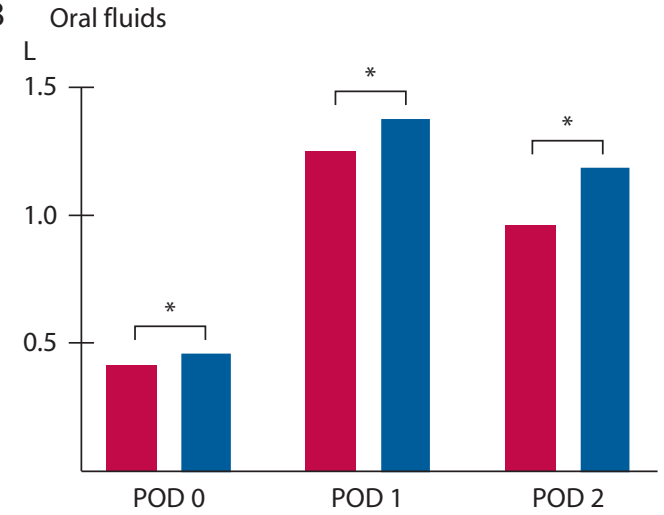

C Weight gain above preoperative body weight $\mathrm{kg}$

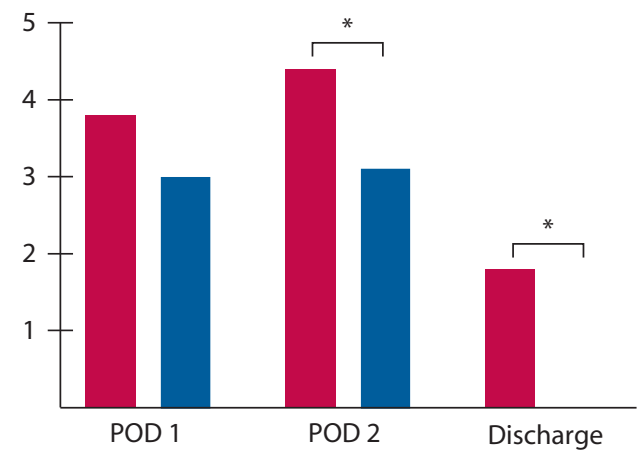

FIGURE 1. Comparison of fluid parameters. Comparison of patients presenting with postoperative ileus $(n=377)$ and patients without postoperative ileus $(n=3828)$. A, Intraoperative and postoperative IV fluid administration. B, Oral fluid intake through POD 0 to 2. C, Weight gain at POD 1, POD 2, and at discharge compared with preoperative body weight. IV = intravenous; $\mathrm{POD}=$ postoperative day. Asterisks indicate significant differences $(p<0.05)$.

further adversely affect GI motility and may lead to prolonged POI (pathologic ileus). ${ }^{31,32}$ These latter findings are supported by the present study, which revealed an independent impact of postoperative complications on POI occurrence. There is strong evidence that fluid overload may contribute to this vicious circle..$^{33}$ Lobo et al ${ }^{34}$ described the critical role of perioperative fluid balance and avoidance of interstitial fluid overload in the elective setting. Weight gain of 2.5 to $3.0 \mathrm{~kg}$ was associated with adverse outcomes in this former study, similar as in the present study. Splanchnic edema may result in increased abdominal pressure with decreased mesenteric blood flow, which in turn elicits tissue hypoxia and ultimately leads to ileus and impaired anastomotic healing. ${ }^{35}$ The present study used previously defined critical fluid threshold $s^{21}$ and revealed indeed an independent impact of fluid overload beyond well-known risk factors for POI to confirm these potential pathogenesis patterns.

Several additional factors may have contributed to ileus prevention in the present study. First, high ERP compliance is of utmost importance, ${ }^{14}$ because outcomes are directly related to adherence to all items of the multimodal pathway. ${ }^{36}$ Systematic PONV prophylaxis has been integrated as standard of care in the present institution. ${ }^{13}$ Of note, PONV prophylaxis has an indirect (central) protective effect through decreased nausea perception but does not address paralytic POI itself. An opioid-sparing pain management strategy with increased use of intrathecal analgesia may further account for decreased ileus rates. ${ }^{17}$ Finally and of crucial importance, immediate retrieval of NGTs after elective surgery allowing early resumption of a normal diet combined with early ambulation help to promote functional recovery, as repeatedly shown previously. ${ }^{37,38}$ Stringent fluid management adds to these concepts and may play a particularly important role, as revealed by this present study. Of note, intraoperative IV fluid administration averaged $\approx 3 \mathrm{~L}$ in the present study with important variations, emphasizing the lack of clear definitions of a restrictive fluid regimen. A former multinational study of the enhanced recovery after surgery network observed that $60 \%$ of patients undergoing colorectal resections exceeded the suggested restrictive fluid threshold of $3 \mathrm{~L} .{ }^{39}$ The thresholds used in this study derive from an independent cohort and intend to provide some help in guidance but should not be considered as a one-size-fits-all recipe. Of note, postoperative AKI occurred at a rate overall of $3 \%$ in the present cohort.

Some limitations need to be considered beyond the retrospective study design. This study revealed a significant association of POI and postoperative complications. Early postoperative complications confound POI occurrence, ${ }^{40}$ whereas, on the other hand, POI itself may entail complications (ie, AKI or pulmonary complications). We tried to further investigate the impact of postoperative complications by analyzing the timing of complication occurrence, revealing that several complications occurred rather late in the postoperative course, after the assessment of fluid overload at POD 0 (IV fluids) and POD 2 (weight). However, the confounding potential of early postoperative complications needs to be strongly emphasized. Several definitions of POI have been suggested. NGT reinsertion may occur for other reasons than POI; nevertheless, this definition has been widely accepted as a hard end point. ${ }^{22}$ The list of potential confounders of POI occurrence is not exhaustive in this study. The impact of ostomy creation on ileus occurrence was not specifically 
TABLE 3. Outcome

\begin{tabular}{|c|c|c|c|c|}
\hline Type of complication & $\begin{array}{c}\text { All } \\
(n=4205)\end{array}$ & $\begin{array}{c}\text { Ileus } \\
(n=377)\end{array}$ & $\begin{array}{l}\text { No ileus } \\
(n=3828)\end{array}$ & $p$ \\
\hline Any complication, n (\%) & $1008(24)$ & $159(42)$ & $849(22)$ & $<0.0001^{*}$ \\
\hline Bleeding complication, $\mathrm{n}$ (\%) & $524(12)$ & $84(22)$ & $440(11)$ & $<0.0001^{*}$ \\
\hline Transfusion POD 1, n (\%) & $145(3)$ & $18(5)$ & $127(3)$ & 0.139 \\
\hline Transfusion POD 2, n (\%) & $103(2)$ & $14(4)$ & $89(2)$ & 0.113 \\
\hline SSI, n (\%) & $115(3)$ & $69(18)$ & $161(4)$ & $<0.0001^{*}$ \\
\hline Reoperation, n (\%) & $248(6)$ & $66(18)$ & $182(5)$ & $<0.0001^{*}$ \\
\hline Readmission, $\mathrm{n}(\%)$ & $543(13)$ & $69(18)$ & $474(12)$ & $0.002 *$ \\
\hline Length of stay, median (IQR), d & $4(2-16)$ & $9(3--16)$ & $4(2-8)$ & $<0.0001^{*}$ \\
\hline
\end{tabular}

Data includes postoperative complications in patients presenting with postoperative ileus $(n=377)$ and patients without postoperative ileus ( $n=3828$ ).

$\mathrm{AKI}=$ acute kidney injury in early postoperative period (only recorded if postoperative creatinine measured), any complication within 30 days: Clavien-Dindo grade I-V; POD

$=$ postoperative day; $\mathrm{SSI}$ = surgical site infection needing invasive treatment (percutaneous, surgical, or negative pressure wound therapy); IQR = interquartile range.

${ }^{*} P$ value $<0.05$ is significant.

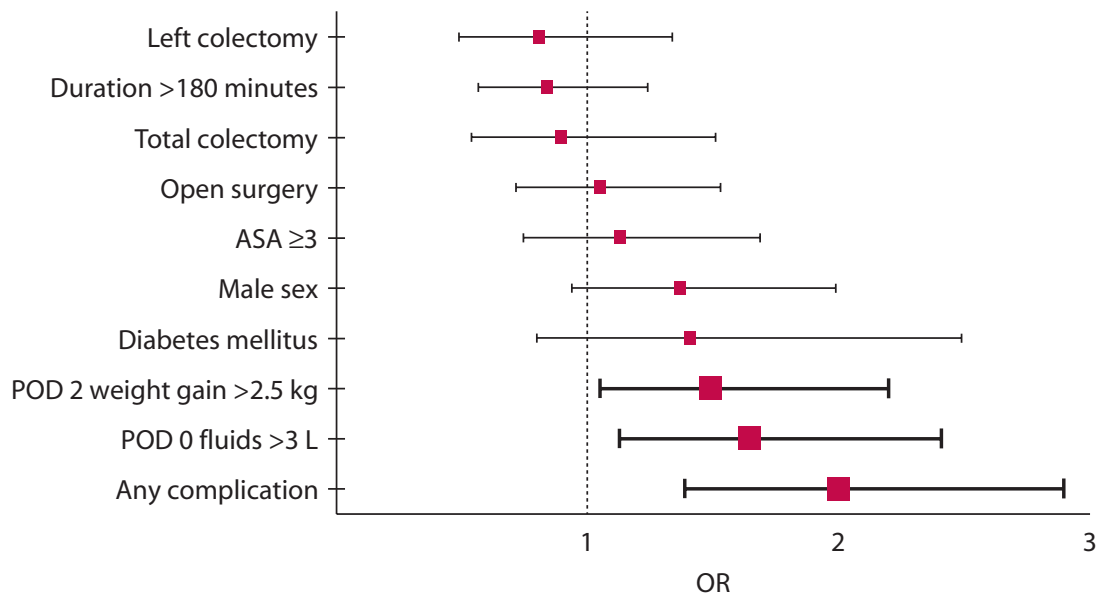

FIGURE 2. Multivariable analysis. Multivariable analysis of univariate demographic, fluid management-related and surgical risk factors ( $p<$ 0.05 ) for postoperative ileus (POI). OR is shown as squares, $95 \% \mathrm{Cl}$ as bars. Values $>1$ increase the likelihood of POI. Bold indicates statistical significance. $\mathrm{POD}=$ postoperative day.

assessed. Furthermore, fluid management depends on various patient-, disease-, and surgery-related factors and cannot be generalized and extrapolated to every patient. However, the large unselected cohort and highly standardized care pathway in this single-center experience account for a homogeneous patient sample.

\section{CONCLUSION}

Restrictive fluid management within a standardized ERP may contribute to lower POI occurrence. This is of importance given the significant association of POI and postoperative morbidity. Avoiding day 0 fluids $>3 \mathrm{~L}$ and a postoperative weight on POD $2>2.5 \mathrm{~kg}$ are likely to improve outcomes after colorectal surgery.

\section{REFERENCES}

1. Ceretti AP, Maroni N, Longhi M, et al. Risk factors for prolonged postoperative ileus in adult patients undergoing elective colorectal surgery: an observational cohort study. Rev Recent Clin Trials. 2018;13:295-304.

2. Huebner M, Hübner M, Cima RR, Larson DW. Timing of complications and length of stay after rectal cancer surgery. J Am Coll Surg. 2014;218:914-919.

3. Biondo S, Miquel J, Espin-Basany E, et al. A double-blinded randomized clinical study on the therapeutic effect of gastrografin in prolonged postoperative ileus after elective colorectal surgery. World J Surg. 2016;40:206-214.

4. Vather R, Josephson R, Jaung R, Kahokehr A, Sammour T, Bissett I. Gastrografin in prolonged postoperative ileus: a doubleblinded randomized controlled trial. Ann Surg. 2015;262:23-30.

5. Adam MA, Lee LM, Kim J, et al. Alvimopan provides additional improvement in outcomes and cost savings in enhanced recovery colorectal surgery. Ann Surg. 2016;264:141-146.

6. Lim P, Morris OJ, Nolan G, Moore S, Draganic B, Smith SR. Sham feeding with chewing gum after elective colorectal resectional surgery: a randomized clinical trial. Ann Surg. 2013;257:1016-1024.

7. de Leede EM, van Leersum NJ, Kroon HM, van Weel V, van der Sijp JRM, Bonsing BA; Kauwgomstudie Consortium. Multicen- 
tre randomized clinical trial of the effect of chewing gum after abdominal surgery. Br J Surg. 2018;105:820-828.

8. Cho JS, Kim HI, Lee KY, et al. Comparison of the effects of patient-controlled epidural and intravenous analgesia on postoperative bowel function after laparoscopic gastrectomy: a prospective randomized study. Surg Endosc. 2017;31:4688-4696.

9. Hübner M, Blanc C, Roulin D, Winiker M, Gander S, Demartines N. Randomized clinical trial on epidural versus patientcontrolled analgesia for laparoscopic colorectal surgery within an enhanced recovery pathway. Ann Surg. 2015;261:648-653.

10. Lobo DN, Bostock KA, Neal KR, Perkins AC, Rowlands BJ, Allison SP. Effect of salt and water balance on recovery of gastrointestinal function after elective colonic resection: a randomised controlled trial. Lancet. 2002;359:1812-1818.

11. Brandstrup B, Tønnesen H, Beier-Holgersen R, et al.; Danish Study Group on Perioperative Fluid Therapy. Effects of intravenous fluid restriction on postoperative complications: comparison of two perioperative fluid regimens: a randomized assessor-blinded multicenter trial. Ann Surg. 2003;238:641-648.

12. Myles PS, Bellomo R, Corcoran T, et al.; Australian and New Zealand College of Anaesthetists Clinical Trials Network and the Australian and New Zealand Intensive Care Society Clinical Trials Group. Restrictive versus liberal fluid therapy for major abdominal surgery. N Engl J Med. 2018;378:2263-2274.

13. Larson DW, Lovely JK, Cima RR, et al. Outcomes after implementation of a multimodal standard care pathway for laparoscopic colorectal surgery. Br J Surg. 2014;101:1023-1030.

14. Lovely JK, Maxson PM, Jacob AK, et al. Case-matched series of enhanced versus standard recovery pathway in minimally invasive colorectal surgery. Br J Surg. 2012;99:120-126.

15. Khreiss W, Huebner M, Cima RR, et al. Improving conventional recovery with enhanced recovery in minimally invasive surgery for rectal cancer. Dis Colon Rectum. 2014;57:557-563.

16. Merchea A, Lovely JK, Jacob AK, et al. Efficacy and outcomes of intrathecal analgesia as part of an enhanced recovery pathway in colon and rectal surgical patients. Surg Res Pract. 2018;2018:8174579.

17. Hübner M, Lovely JK, Huebner M, Slettedahl SW, Jacob AK, Larson DW. Intrathecal analgesia and restrictive perioperative fluid management within enhanced recovery pathway: hemodynamic implications. J Am Coll Surg. 2013;216:1124-1134.

18. Thiele RH, Raghunathan K, Brudney CS, et al.; Perioperative Quality Initiative (POQI) I Workgroup. American Society for Enhanced Recovery (ASER) and Perioperative Quality Initiative (POQI) joint consensus statement on perioperative fluid management within an enhanced recovery pathway for colorectal surgery. Perioper Med (Lond). 2016;5:24.

19. Holubar SD, Hedrick T, Gupta R, et al.; Perioperative Quality Initiative (POQI) I Workgroup. American Society for Enhanced Recovery (ASER) and Perioperative Quality Initiative (POQI) joint consensus statement on prevention of postoperative infection within an enhanced recovery pathway for elective colorectal surgery. Perioper Med (Lond). 2017;6:4.

20. Gupta R, Gan TJ. Peri-operative fluid management to enhance recovery. Anaesthesia. 2016;71(suppl 1):40-45.

21. Pache B, Hübner M, Solà J, Hahnloser D, Demartines N, Grass F. Receiver operating characteristic analysis to determine optimal fluid management during open colorectal surgery. Colorectal Dis. 2019;21:234-240.

22. Vather R, Trivedi S, Bissett I. Defining postoperative ileus: results of a systematic review and global survey. J Gastrointest Surg. 2013;17:962-972.
23. Wolthuis AM, Bislenghi G, Fieuws S, de Buck van Overstraeten A, Boeckxstaens G, D'Hoore A. Incidence of prolonged postoperative ileus after colorectal surgery: a systematic review and meta-analysis. Colorectal Dis. 2016;18:O1-O9.

24. Yorkshire Surgical Research Collaborative. Multicentre observational study of gastrointestinal recovery after elective colorectal surgery. Colorectal Dis. 2018;20:536-544.

25. Choi JW, Kim DK, Kim JK, Lee EJ, Kim JY. A retrospective analysis on the relationship between intraoperative hypothermia and postoperative ileus after laparoscopic colorectal surgery. PLoS One. 2018;13:e0190711.

26. Grass F, Slieker J, Jurt J, et al. Postoperative ileus in an enhanced recovery pathway-a retrospective cohort study. Int J Colorectal Dis. 2017;32:675-681.

27. Venara A, Neunlist M, Slim K, et al. Postoperative ileus: pathophysiology, incidence, and prevention. J Visc Surg. 2016;153:439-446.

28. Cabellos Olivares M, Labalde Martínez M, Torralba M, Rodríguez Fraile JR, Atance Martínez JC. C-reactive protein as a marker of the surgical stress reduction within an ERAS protocol (enhanced recovery after surgery) in colorectal surgery: a prospective cohort study. J Surg Oncol. 2018;117:717-724.

29. Barbieux J, Hamy A, Talbot MF, et al. Does enhanced recovery reduce postoperative ileus after colorectal surgery? J Visc Surg. 2017;154:79-85.

30. Türler A, Moore BA, Pezzone MA, Overhaus M, Kalff JC, Bauer AJ. Colonic postoperative inflammatory ileus in the rat. Ann Surg. 2002;236:56-66.

31. Artinyan A, Nunoo-Mensah JW, Balasubramaniam S, et al. Prolonged postoperative ileus-definition, risk factors, and predictors after surgery. World J Surg. 2008;32:1495-1500.

32. Chapuis PH, Bokey L, Keshava A, et al. Risk factors for prolonged ileus after resection of colorectal cancer: an observational study of 2400 consecutive patients. Ann Surg. 2013;257:909-915.

33. Lobo DN. Fluid overload and surgical outcome: another piece in the jigsaw. Ann Surg. 2009;249:186-188.

34. Lobo DN, Macafee DA, Allison SP. How perioperative fluid balance influences postoperative outcomes. Best Pract Res Clin Anaesthesiol. 2006;20:439-455.

35. Mayberry JC, Welker KJ, Goldman RK, Mullins RJ. Mechanism of acute ascites formation after trauma resuscitation. Arch Surg. 2003;138:773-776.

36. Gustafsson UO, Hausel J, Thorell A, Ljungqvist O, Soop M, Nygren J; Enhanced Recovery After Surgery Study Group. Adherence to the enhanced recovery after surgery protocol and outcomes after colorectal cancer surgery. Arch Surg. 2011;146:571-577.

37. Sanfilippo F, Spoletini G. Perspectives on the importance of postoperative ileus. Curr Med Res Opin. 2015;31:675-676.

38. Mariani P, Slim K. Enhanced recovery after gastro-intestinal surgery: the scientific background. J Visc Surg. 2016;153(6S):S19-S25.

39. Group EC; ERAS Compliance Group. The impact of enhanced recovery protocol compliance on elective colorectal cancer resection: results from an international registry. Ann Surg. 2015;261:1153-1159.

40. Venara A, Alfonsi P, Cotte E, Loriau J, Hamel JF, Slim K; Francophone Group for Enhanced Recovery After Surgery (GRACE). Postoperative ileus concealing intra-abdominal complications in enhanced recovery programs-a retrospective analysis of the GRACE database. Int J Colorectal Dis. 2019;34:71-83. 